\title{
Close Encounters of the Third (Space) Kind: La guaracha del Macho Camacho and the City as Site of Unavoidable Contact
}

\author{
Chris T. Schulenburg ${ }^{1}$
}

Friction in language is inevitable and unruly. Lexical, grammatical, and contextual issues require linguistic negotiation for both native and second-language speakers. This preoccupation with language is heightened by the tug-of-war of linguistic power occasioned by Puerto Rico's commonwealth status in relation to the United States. My essay "Close Encounters of the Third (Space) Kind: La guaracha del Macho Camacho and the City as Site of Unavoidable Contact" examines the image of the city of San Juan in this Luis Rafael Sánchez novel as a luminal, metaphorical space to dramatize these linguistic tensions. Specifically, this analysis argues that Puerto Rico's urban colossus functions as a hybrid "Third Space" in which daily encounters with the island's "others" metaphorically demonstrate a negotiated, intercultural, and truly Puerto Rican space. [Article copies available for a fee from The Transformative Studies Institute. E-mail address: journal@transformativestudies.org Website: http://www.transformativestudies.org (C2010 by The Transformative Studies Institute. All rights reserved.]

KEYWORDS: La guaracha del Macho Camacho, Luis Rafael Sánchez, Homi Bhabha, Postcolonial Theory, Puerto Rican Literature, Urban studies.

The massive walls surrounding colonial Latin American island cities such as San Juan highlight the problems of limits as well as protection for its expanding urban area. In particular, San Juan's coastal location and the Caribbean island's vulnerability to invasion and looting by pirates necessitated a certain measure of enclosure. Nevertheless, these physically imposing boundaries do not guarantee any sense of spatial control over the Caribbean region in general. As Antonio Benítez Rojo

\footnotetext{
${ }^{1}$ Chris T. Schulenburg, Ph.D., is an Assistant Professor of Latin American Literature and Culture at the University of Wisconsin-Platteville. He teaches courses on Colonial and Modern Latin American Literatures. At the moment, his investigative focus centers on the aesthetic image of the city and intellectual in twentieth-century Argentine literature. Address correspondence to: Chris T. Schulenburg, University of WisconsinPlatteville, 1 University Circle-229 Warner Hall, Platteville, WI 53818; e-mail: schulenburge@uwplatt.edu.
} 